\title{
Terpenoids and Sterols from Hoya multiflora Blume
}

\author{
Virgilio D. Ebajo Jr. ${ }^{1}$, Chien-Chang Shen ${ }^{2}$, Consolacion Y. Ragasa ${ }^{1,3^{*}}$ \\ ${ }^{1}$ Chemistry Department, De La Salle University, 2401 Taft Avenue, Manila 1004, Philippines. ${ }^{2}$ National Research Institute of Chinese Medicine, 155-1, Li- \\ Nong St., Sec. 2, Taipei 112, Taiwan. ${ }^{3}$ Chemistry Department, De La Salle University Science \& Technology Complex Leandro V. Locsin Campus, Binan \\ City, Laguna 4024, Philippines.
}

\section{ARTICLE INFO \\ Article history: \\ Received on: 30/01/2015 \\ Revised on: $12 / 02 / 2015$ \\ Accepted on: 07/03/2015 \\ Available online: 27/04/2015 \\ Key words: \\ Hoya multiflora Blume, Apocynaceae, bauerenol, lupeol, lupeol acetate, $\alpha$ - amyrin, $\alpha$-amyrin acetate, $\beta$ - amyrin, $\beta$-amyrin acetate, squalene, lutein, $\beta$-sitosterol, stigmasterol.}

\begin{abstract}
Chemical investigation of the dichloromethane extracts of Hoya multiflora Blume led to the isolation of lupeol (1a), $\alpha$-amyrin (1) $), \beta$-amyrin (1c), lupeol acetate (2a), $\alpha$-amyrin acetate $(\mathbf{2 b})$, and $\beta$-amyrin acetate (2c) from the stems; and $\mathbf{1 b}$, bauerenol (3), squalene (4), lutein (5), $\beta$-sitosterol (6a), and stigmasterol (6b)from the leaves. The structures of 1-6 were identified by comparison of their ${ }^{1} \mathrm{H}$ and/or ${ }^{13} \mathrm{C}$ NMR data with those reported in the literature.
\end{abstract}

\section{INTRODUCTION}

Hoya plants are also called wax plants due to the waxy appearance of their leaves or flowers. There are at least 109 species of Hoya found in the Philippines, 88 of these are endemic to the country (Aurigue, 2013). The Hoya multiflora, also called shooting-star hoya is indigenous to the Philippines. This plant was called multiflora due to its multiple flowers (about 40) in the convex umbel (Aurigue, 2013). There are no reported chemical studies and biological activities on $H$. multiflora. However, congeners of the plant have been studied for their chemical constituents. Gas chromatographic analysis on the chemical constituents of Hoya naumanii led to the detection of the triterpenes $\beta$-amyrin, lupeol and $\alpha$-amyrin and their 3, 4-seco-3oic acid methyl esters (Baas and Van Berkel, 1991). The isolation of pentacyclic triterpenols $\delta$-amyrin, $\beta$-amyrin, lupeol and $\alpha$-amyrin and their 3, 4-seco-3-nor-2-ol derivatives (australinols A-D) from the leaf wax, of, Hoya australis, have

\footnotetext{
* Corresponding Author

Consolacion Y. Ragasa, Chemistry Department, De La Salle University, 2401 Taft Avenue, Manila 1004, Philippines.

Email: consolacion.ragasa@dlsu.edu.ph
}

been reported (Baas et al., 1992). Moreover, the $\beta$-amyrin derivative 5-isopropyl-10 (2-methoxycarbonylethyl)des-A-olean12-en and the taraxerol derivative 5-isopropyl-10 (2methoxycarbonylethyl)des-A-olean-14-en were isolated from Hoya lacunose (Baas, 1983). The oligosaccharides 6-deoxy-3-, O-methyl$\beta$-allopyranosyl $(1 \rightarrow 4)-\beta$-cymaropyranosyl $(1 \rightarrow 4)-\beta$-cymaronic acid $\delta$-lactone and 6-deoxy-3- $O$-methyl- $\beta$-allopyranosyl $(1 \rightarrow 4)-\beta$ oleandropyranosyl $(1 \rightarrow 4)$ - $\beta$-cymaropyranosyl $(1 \rightarrow 4)$ - $\beta$-cymaronic acid $\delta$-lactone and its sodium salt were isolated from Hoya carnosa (Yoshikawa et al., 2000). A review on the chemical and pharmacological aspects of Hoya species has been provided (Pandey et al., 2006). Hoya species yielded pregnanes, lipids, sterols, flavanols, triterpenes, sesquiterpenes and disaccharides. They were reported to exhibit antinematodal activity, hypo sensitization, immunological properties and phytotoxicity; used for the treatment of occupational asthma and sea-squirt asthma and allergies; and employed as antigens and insecticides (Pandey et al., 2006).

This study was conducted as part of our research on the chemical constituents of the genus Hoya. We earlier, reported the isolation of lupenone and lupeol from the roots; lupeol, squalene and $\beta$-sitosterol from the leaves; and betulin from, the stems of Hoya mindorensis Schlechter (Ebajo et al., 2014). 

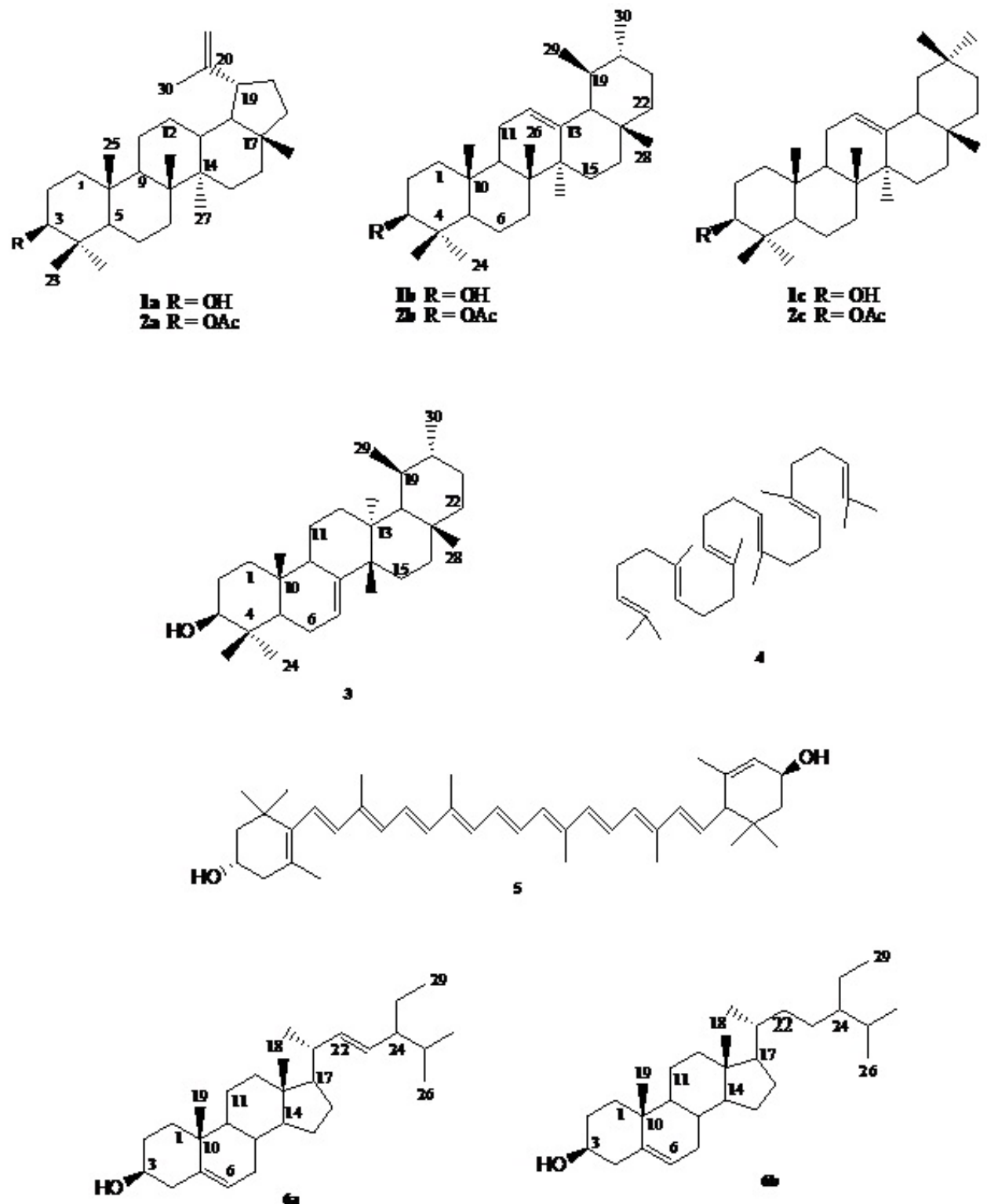

Fig. 1: Chemical Constituents of Hoya multiflora lupeno (1a), lupeol acetate (2a), $\alpha$-amyrin (1b), $\alpha$-amyrin acetate (2b), $\beta$-amyrin (1c), $\beta$-amyrin acetate (2a), bauerenol (3), squalene (4), lutein (5), $\beta$-sitosterol (6a), and stig masterol (6b).

We report herein the isolation of lupeol (1a), $\alpha$-amyrin (1) $), \beta$-amyrin (1c), lupeol acetate (2a), $\alpha$-amyrin acetate (2b), and $\beta$-amyrin acetate (2c) from the stems; and $\mathbf{1 b}$, bauerenol (3), squalene (4), lutein (5), $\beta$-sitosterol (6a), and stigmasterol $(\mathbf{6 b})$ from the leaves of Hoya multiflora Blume. To the best of our knowledge this is the first report on the isolation of these compounds from $H$. multiflora.

\section{MATERIALS AND METHODS}

\section{General Experimental Procedure}

NMR spectra were recorded on a Varian VNMRS spectrometer in $\mathrm{CDCl}_{3}$ at $600 \mathrm{MHz}$ for ${ }^{1} \mathrm{H} \mathrm{NMR}$ and $150 \mathrm{MHz}$ for ${ }^{13} \mathrm{C}$ NMR spectra. Column chromatography was performed, with silica gel 60 (70-230 mesh). Thin layer chromatography, was performed with plastic backed plates coated with silica gel $\mathrm{F}_{254}$ and the plates were visualized by spraying with vanillin $/ \mathrm{H}_{2} \mathrm{SO}_{4}$ solution followed by warming.

\section{Sample Collection}

Hoya multiflora Blume was collected from a garden in Pangasinan, Philippines in September 2013. Voucher specimens were authenticated at the Botany Division of the Philippine National Museum.

\section{General Isolation Procedure}

The air-dried leaves $(23.0 \mathrm{~g})$, and stems $(86.5 \mathrm{~g})$ of $H$. multiflora were ground in a blender, soaked in $\mathrm{CH}_{2} \mathrm{Cl}_{2}$ for three days and then filtered. The filtrates were concentrated under vacuum to afford crude extracts of leaves $(2.0 \mathrm{~g})$, and stems $(1.0 \mathrm{~g})$ 
which were each chromatographed by gradient elution with $\mathrm{CH}_{2} \mathrm{Cl}_{2}$, followed by increasing amounts of acetone at $10 \%$ increment by volume as eluents. A glass column 12 inches in height and 0.5 inch internal diameter was used for the fractionation of crude extracts. Two milliliter fractions were collected. Fractions with spots of the same $R_{f}$ values were combined and rechromatographed in appropriate solvent systems until TLC pure isolates were obtained. Rechromatography and final purifications were conducted using Pasteur pipettes as columns. One milliliter fractions were collected.

\section{Isolation of Chemical Constituents of the Stems}

The $\mathrm{CH}_{2} \mathrm{Cl}_{2}$ fraction from the chromatography of the crude extract was rechromatographed using $1 \%$ EtOAc in petroleum ether to afford a mixture of $\mathbf{2 a - 2} \mathbf{c}(9 \mathrm{mg})$ after washing with petroleum ether. The $20 \%$ acetone in $\mathrm{CH}_{2} \mathrm{Cl}_{2}$ fraction was rechromatographed using 5\% EtOAc in petroleum ether, to afford a mixture of 1a-1c (4 mg) after washing with petroleum ether.

\section{Isolation of Chemical Constituents of the Leaves}

The $\mathrm{CH}_{2} \mathrm{Cl}_{2}$ fraction from the chromatography of the crude extract was rechromatographed $(3 \times)$ using petroleum ether to afford $4(5 \mathrm{mg})$. The $30 \%$ acetone in $\mathrm{CH}_{2} \mathrm{Cl}_{2}$ fraction was rechromatographed $(4 \times)$ using $20 \%$ EtOAc in petroleum ether to afford a mixture of $\mathbf{1 b}$ and $\mathbf{3}$ (15 $\mathrm{mg}$ ) after washing with petroleum ether. The $40 \%$ acetone in $\mathrm{CH}_{2} \mathrm{Cl}_{2}$ fraction was rechromatographed (2x) using $\mathrm{CH}_{3} \mathrm{CN}: \mathrm{Et}_{2} \mathrm{O}: \mathrm{CH}_{2} \mathrm{Cl}_{2}(0.5: 0.5: 9$, v/v) afford a mixture of $6 \mathbf{a}$ and $\mathbf{6 b}(4 \mathrm{mg})$ after washing with petroleum ether. The $60 \%$ acetone in $\mathrm{CH}_{2} \mathrm{Cl}_{2}$ fraction was rechromatographed using $\mathrm{CH}_{3} \mathrm{CN}: \mathrm{Et}_{2} \mathrm{O}: \mathrm{CH}_{2} \mathrm{Cl}_{2}(1: 1: 8, \mathrm{v} / \mathrm{v})$ afford $5(3 \mathrm{mg})$ after washing with $\mathrm{Et}_{2} \mathrm{O}$.

\section{Lupeol (1a)}

Colorless solid. ${ }^{1} \mathrm{H}$ NMR (600 MHz, $\left.\mathrm{CDCl}_{3}\right): \delta 4.66(\mathrm{~d}, J$ $=2.4 \mathrm{~Hz}, \mathrm{H}-29 \mathrm{~b}), 4.55$ (d, $J=2.4 \mathrm{~Hz}, \mathrm{H}-29 \mathrm{a}), 3.18$ (H-3), 0.98 (s, $\mathrm{H}_{3}-23$ ), 0.78 (s, $\left.\mathrm{H}_{3}-24\right), 0.83$ (s, $\left.\mathrm{H}_{3}-25\right), 0.95$ (s, $\left.\mathrm{H}_{3}-26\right), 1.05$ (s, $\left.\mathrm{H}_{3}-27\right), 0.90$ (s, $\left.\mathrm{H}_{3}-28\right), 1.66$ (s, $\mathrm{H}_{3}-30$ ).

\section{$\alpha$-Amyrin (1b)}

Colorless solid. ${ }^{1} \mathrm{H}$ NMR $\left(600 \mathrm{MHz}, \mathrm{CDCl}_{3}\right): \delta 3.15(\mathrm{H}-$ 3), 0.67 (H-5), 5.12 (H-12), 0.95 (s, H $\left.\mathrm{H}_{3}-23\right), 0.76$ (s, H $\left.\mathrm{H}_{3}-24\right), 0.75$ (s, $\left.\mathrm{H}_{3}-25\right), 0.89$ (s, $\left.\mathrm{H}_{3}-26\right), 1.01$ (s, $\left.\mathrm{H}_{3}-27\right), 0.95$ (s, $\left.\mathrm{H}_{3}-28\right), 0.85$ (d, $\left.J=6.0 \mathrm{~Hz}, \mathrm{H}_{3}-29\right), 0.75$ (d, $J=7.0 \mathrm{~Hz}, \mathrm{H}_{3}-30$ ).

\section{B-Amyrin (1c)}

Colorless solid. ${ }^{1} \mathrm{H}$ NMR $\left(600 \mathrm{MHz}, \mathrm{CDCl}_{3}\right): \delta 3.15(\mathrm{H}-$ 3), 0.67 (H-5), 5.16 (H-12), 0.77 (s, H $\left.\mathrm{H}_{3}-23\right), 0.90$ (s, H $\left.\mathrm{H}_{3}-24\right), 0.74$ (s, $\mathrm{H}_{3}-25$ ), 0.93 (s, $\left.\mathrm{H}_{3}-26\right), 1.16$ (s, $\left.\mathrm{H}_{3}-27\right), 1.07$ (s, $\left.\mathrm{H}_{3}-28\right), 0.86$ (s, $\left.\mathrm{H}_{3}-29\right), 0.79$ (s, $\mathrm{H}_{3}-30$ ).

\section{Lupeol acetate (2a)}

Colorless solid. ${ }^{13} \mathrm{C}$ NMR $\left(150 \mathrm{MHz}, \mathrm{CDCl}_{3}\right): \delta 38.44$ (C-1), 27.42 (C-2), 80.94 (C-3), 38.44 (C-4), 55.36 (C-5), 17.99
(C-6), 34.19 (C-7), 55.41 (C-8), 50.32 (C-9), 37.06 (C-10), 20.92 (C-11), 25.07 (C-12), 38.02 (C-13), 42.05 (C-14), 27.42 (C-15), 35.55 (C-16), 47.63 (C-17), 48.27 (C-18), 47.99 (C-19), 150.96 (C-20), 29.81 (C-21), 40.01 (C-22), 28.07 (C-23), 15.72 (C-24), 15.96 (C-25), 16.17 (C-26), 14.49 (C-27), 18.22, 18.25 (C-28, C30), 109.34 (C-29), 171.01, 21.39 (OAc).

\section{$\alpha-$ Amyrin acetate (2b)}

Colorless solid. ${ }^{13} \mathrm{C}$ NMR $\left(150 \mathrm{MHz}, \mathrm{CDCl}_{3}\right): \delta 38.44$ (C-1), 27.59 (C-2), 80.96 (C-3), 37.69C-4), 55.24 (C-5), 18.22 (C6), 32.85 (C-7), 40.01 (C-8), 47.63 (C-9), 36.77 (C-10), 23.35 (C11), 124.30 (C-12), 139.61 (C-13), 42.05 (C-14), 26.58 (C-15), 28.05 (C-16), 33.73 (C-17), 59.04 (C-18), 39.63 (C-19), 39.59 (C20), 31.23 (C-21), 41.52 (C-22), 28.73 (C-23), 16.85 (C-24), 15.72 (C-25), 16.73 (C-26), 23.21 (C-27), 28.73 (C-28), 17.50 (C-29), 21.39 (C-30), 171.01, 21.32 (OAc).

\section{$\beta$-Amyrin acetate (2c)}

Colorless solid. ${ }^{13} \mathrm{C}$ NMR (150 MHz, $\left.\mathrm{CDCl}_{3}\right), \delta 39.59$ (C-1), 27.93 (C-2), 80.8 (C-3), 39.59 (C-4), 55.24 (C-5), 18.19 (C6), 33.73 (C-7), 38.37 (C-8), 47.4 (C-9), 35.55 (C-10), 23.59 (C11), 121.62 (C-12), 145.20 (C-13), 42.05 (C-14), 28.73 (C-15), 27.93 (C-16), 32.85 (C-17), 59.0 (C-18), 40.01 (C-19), 41.52 (C20), 31.23 (C-21), 42.01 (C-22), 29.69 (C-23), 15.72 (C-24), 15.72 (C-25), 16.84 (C-26), 23.59 (C-27), 28.73 (C-28), 17.50 (C-29), 21.39 (C-30), 170.8, 21.32 (OAc).

\section{Bauerenol (3)}

Colorless solid. ${ }^{13} \mathrm{C}$ NMR (150 MHz, $\left.\mathrm{CDCl}_{3}\right): 36.87(\mathrm{C}-$ 1), 27.69 (C-2), 79.05 (C-3), 38.88 (C-4), 50.41 (C-5), 24.15 (C6), 116.43 (C-7), 145.35 (C-8), 48.22 (C-9), 35.33 (C-10), 16.85 (C-11), 32.42 (C-12), 37.69 (C-13), 41.52 (C-14), 28.87 (C-15), 37.69 (C-16), 32.04 (C-17), 54.88 (C-18), 35.20 (C-19), 32.04 (C20), 29.67 (C-21), 31.52 (C-22), 27.53 (C-23), 14.66 (C-24), 12.98 (C-25), 23.65 (C-26), 22.66 (C-27), 39.65 (C-28), 25.63 (C-29), 22.55 (C-30).

\section{Squalene (4)}

Colorless oil. ${ }^{13} \mathrm{C}$ NMR $\left(150 \mathrm{MHz}, \mathrm{CDCl}_{3}\right): \delta 25.69(\mathrm{C}-$ 1), 131.24 (C-2), 124.31 (C-3), 26.66 (C-4), 39.74 (C-5), 134.89 (C-6), 124.41 (C-7), 26.77 (C-8), 39.76 (C-9), 135.10 (C-10), 124.31 (C-11), 28.28 (C-12), 17.68 (C-13), 16.04 (C-14), 16.00 (C-15).

\section{Lutein (5)}

Orange crystals. ${ }^{1} \mathrm{H} \mathrm{NMR}\left(600 \mathrm{MHz}, \mathrm{CDCl}_{3}\right): \delta 1.05(\mathrm{~s}$, 2 ring $\mathrm{A} \mathrm{CH}_{3}$ ), 0.83 (s, ring $\mathrm{B} \mathrm{CH}_{3}$ ), 0.98 (s, ring $\mathrm{B} \mathrm{CH}_{3}$ ), 1.60 (allylic $\mathrm{CH}_{3}$ ), 1.71 (allylic $\mathrm{CH}_{3}$ ), 1.89 (allylic $\mathrm{CH}_{3}$ ), 1.951 (allylic $\left.\mathrm{CH}_{3}\right), 1.94$ (2 allylic $\left.\mathrm{CH}_{3}\right), 1.45,1.75\left(\mathrm{CH}_{2}\right), 1.35,1.85\left(\mathrm{CH}_{2}\right)$, 2.35, 2.00 (allylic $\mathrm{CH}_{2}$ ), 2.38 (allylic $\mathrm{CH}$ ), 4.23 (br s, $\mathrm{CHOH}$ ), 3.98 $(\mathrm{m}, \mathrm{CHOH}), 5.52(\mathrm{br} \mathrm{s},=\mathrm{CH}), 5.41(\mathrm{dd}, J=9.6,15.0 \mathrm{~Hz},=\mathrm{CH})$, $6.56-6.65,6.33(\mathrm{dd}, J=15.0,3.0 \mathrm{~Hz}), 6.23(\mathrm{br} \mathrm{d}, J=9.6 \mathrm{~Hz})$, 6.09-6.14 (=CH). 


\section{$\beta$-Sitosterol (6a)}

Colorless solid. ${ }^{1} \mathrm{H}$ NMR $\left(600 \mathrm{MHz}, \mathrm{CDCl}_{3}\right): \delta 3.50(\mathrm{~m}$, H-3), 2.26, $2.21\left(\mathrm{H}_{2}-4\right), 5.33$ (dd, $\left.J=1.8,4.8 \mathrm{~Hz}, \mathrm{H}-6\right), 0.66$ (s, $\left.\mathrm{CH}_{3}-18\right), 0.99$ (s, $\left.\mathrm{CH}_{3}-19\right), 0.90$ (d, $\left.J=6.6 \mathrm{~Hz}, \mathrm{CH}_{3}-21\right), 0.79$ (d, $J$ $\left.=6.6 \mathrm{~Hz}, \mathrm{CH}_{3}-26\right), 0.82\left(\mathrm{~d}, J=6.6 \mathrm{~Hz}, \mathrm{CH}_{3}-27\right), 0.86(\mathrm{t}, J=7.2$ $\left.\mathrm{Hz}, \mathrm{CH}_{3}-29\right)$.

\section{Stigmasterol (6b)}

Colorless solid. ${ }^{1} \mathrm{H} \mathrm{NMR}\left(600 \mathrm{MHz}, \mathrm{CDCl}_{3}\right): \delta 3.50(\mathrm{~m}$, H-3), 5.33 (dd, $J=1.8,4.8 \mathrm{~Hz}, \mathrm{H}-6), 0.68$ (s, $\mathrm{CH}_{3}-18$ ), 0.99 (s, $\mathrm{CH}_{3}-19$ ), 1.01 (d, $J=6.6 \mathrm{~Hz}, \mathrm{CH}_{3}-21$ ), 5.13 (dd, $J=8.4,15.0 \mathrm{~Hz}$, $\mathrm{H}-22), 5.00$ (dd, $J=9.0,15.0 \mathrm{~Hz}, \mathrm{H}-23), 0.84$ (d, $J=6.6 \mathrm{~Hz}, \mathrm{CH}_{3^{-}}$ 26), 0.83 (d, $\left.J=6.6 \mathrm{~Hz}, \mathrm{CH}_{3}-27\right), 0.80$ (t, $\left.J=6.6 \mathrm{~Hz}, \mathrm{CH}_{3}-29\right)$.

\section{RESULTS AND DISCUSSION}

Silica gel chromatography of the dichloromethane extracts of Hoya multiflora Blume afforded a mixture of lupeol (1a) (Ragasa et al., 2014a), $\alpha$-amyrin (1b) (Ragasa et al., 2014a) and $\beta$-amyrin (1c) (Ragasa et al., 2014a) in about 2:1:0.3 ratio and another mixture of lupeol acetate (2a) (Tsai et al., 2012), $\alpha$-amyrin acetate (2b) (Ragasa et al., 2014b) and $\beta$-amyrin acetate (2c) (Feleke and Brehane, 2005) in about 3:1:0.3 ratio from the stems; and a mixture of $\mathbf{1 b}$ and bauerenol (3) (Raga et al., 2013a) in about 1:2.5 ratio, squalene (4) (Ragasa et al., 2014c), lutein (5) (Ragasa et al., 2014d), and another mixture of $\beta$-sitosterol (6a) (Ragasa et al., 2014e) and stigmasterol (6b) (Ragasa et al., 2014e) in about $2: 1$ ratio from the leaves. The ratio of about 2:1:0.3 for the mixture of 1a, $\mathbf{1 b}$ and 1c was deduced from integrations of the ${ }^{1} \mathrm{H}$ NMR resonances for the olefinic protons of $1 \mathbf{a}$ at $\delta 4.55(\mathrm{~d}, J=2.4 \mathrm{~Hz})$ and $4.66(\mathrm{~d}, J=2.4 \mathrm{~Hz}), \mathbf{1 b}$ at $\delta 5.10(\mathrm{t}, J=3.6 \mathrm{~Hz})$ and $\mathbf{1 c}$ at $\delta$ $5.16(\mathrm{t}, J=3.6 \mathrm{~Hz})$. The integrations of the ${ }^{1} \mathrm{H}$ NMR resonances for the olefinic protons of $2 \mathbf{a}$ at $\delta 4.55(\mathrm{~d}, J=2.4 \mathrm{~Hz})$ and $4.66(\mathrm{~d}, J$ $=2.4 \mathrm{~Hz}), \mathbf{2 b}$ at $\delta 5.11(\mathrm{t}, J=3.6 \mathrm{~Hz})$ and $\mathbf{2 c}$ at $\delta 5.16(\mathrm{t}, J=3.6$ $\mathrm{Hz}$ ) indicated that the ratio of $\mathbf{2 a}, \mathbf{2} \mathbf{b}$ and $\mathbf{2} \mathbf{c}$ is about $3: 1: 0.3$. The 1:2.5 ratio of the mixture of $\mathbf{1 b}$ and $\mathbf{3}$ was determined from the integrations of the ${ }^{1} \mathrm{H}$ NMR resonances for the olefinic protons of $\mathbf{1 b}$ at $\delta 5.15(\mathrm{t}, J=3.6 \mathrm{~Hz})$ and 3 at $\delta 5.39(\mathrm{dd}, J=3.0,7.2 \mathrm{~Hz}, \mathrm{H}-$ 7). The integrations of the ${ }^{1} \mathrm{H}$ NMR resonances for the olefinic protons of $\mathbf{6 a}$ at $\delta 5.33(\mathrm{H}-6)$ and $\mathbf{6 b}$ at $\delta 5.33(\mathrm{H}-6), 5.13(\mathrm{dd}, J=$ 8.4, $15.0 \mathrm{~Hz}, \mathrm{H}-22)$ and $5.00(\mathrm{dd}, J=8.4,15.0 \mathrm{~Hz}, \mathrm{H}-23)$ suggested that the ratio of $\mathbf{6 a}$ and $\mathbf{6 b}$ is about $2: 1$. The structures of 1-6 were identified by comparison of their ${ }^{1} \mathrm{H}$ and/or ${ }^{13} \mathrm{C}$ NMR data with literature data.

Although no biological activity tests were conducted on the isolated compounds (1-6), literature search revealed that these have diverse bioactivities as follows., Lupeol (1a) exhibited antiurolithiatic and diuretic activity (Vidya et al., 2002). It prevented the formation ofvesical calculi and reduced the size of the preformed stones in rats (Anand et al., 1994). It also showed antifungal activity against Fusarium oxysporum and Penicillium notatum (Manzano et al., 2013). Lupeol significantly reduced the 451Lu tumor growth in athymic nude mice (Saleemet al., 2008), inhibited the proliferation of MDA-MB-231 human breast cancer cells in a dose dependent manner (Lambertini et al., 2005), and induced growth inhibition and apoptosis in hepatocellular carcinoma SMMC7721 cells by down-regulation of the death receptor 3 (DR3) expression (Zhang et al., 2009). Lupeol and lupeol acetate (2a) have shown hypotensive activity (Saleem et al., 2003), while 1a also exhibited antidyslipidemic activity in hamster at $100 \mathrm{mg} / \mathrm{Kg}$ body weight (Reddy et al., 2009). It exhibited potent anti-inflammatory activity in an allergic airway inflammation model by a significant reduction in eosinophils infiltration and in Th2-associated cytokines levels that trigger the immune responses in asthma (Vasconcelos et al., 2008). A review on the biological activities of lupeol has been provided (Gallo and Sarachine, 2009). $\beta$-Amyrin (1c) and $\alpha$-amyrin (1b) were reported to possess antiinflammatory (Recio et al., 1995; Madeiros et al., 2007; Okoye et al., 2014) and analgesic (Otuki et al., 2005; Soldi et al., 2008) properties. $\beta$-Amyrin showed antifungal activity against $A$. rabiei with an MIC value of $0.0156 \mathrm{mg} / \mathrm{mL}$ (Jabeen et al., 2011), $\alpha$ Amyrin was proposed as a possible biomarker for the fungal resistance of grape-vine leaves (Vitis vinifera) (Batovska et al., 2008). The mixture of $\mathbf{1 b}$ and $\mathbf{1 c}$ effectively reduced the elevated plasma glucose levels during the oral glucose tolerance test (OGTT). Furthermore, the mixture of $\mathbf{1 b}$ and $\mathbf{1 c}$ at $100 \mathrm{mg} / \mathrm{kg}$ significantly decreased the VLDL and LDL cholesterol and increased the HDL cholesterol (Santos et al., 2012). A review on the sources and biological activities of $\mathbf{1 b}$ and $\mathbf{1 c}$ has been provided (Vasquez et al., 2012). The anti-inflammatory effect of lupeol acetate (2a) involves the opioid system, as indicated by the complete blockade of the opioid antagonist naloxone (Lucetti et al., 2010). $\alpha$-Amyrin acetate (2b) at $100 \mathrm{mg} / \mathrm{kg}$ showed significant $(p<0.05)$ inhibition of egg albumen-induced paw edema with 40 $\%$ inhibition at the 5 th hour. $\beta$-Amyrin acetate $(\mathbf{2 c})$ and $\mathbf{2 b}$ isolated from the Alstonia boonei stem bark exhibited profound antiinflammatory activity (Okoye et al., 2014). Triterpenes $\mathbf{2 b}$ and $\mathbf{2 c}$ were also reported to exhibit sedative, anxiolytic and anticonvulsant properties (Aragao et al., 2009). A mixture of bauerenol (3), 1b and 1c obtained from Ardisia species exhibited angio-suppressive effects on duck chorioallantoic membrane (CAM) (Raga et al., 2013b); restricted inter-capillary length and reduced branch point with $100 \%$ CAM viability and embryo survivability and promoted intense expression of the von Willebrand factor (F8) (Raga et al., 2013c); was found toxic to $A$. salina nauplii after $48 \mathrm{~h}$ of exposure and showed teratologic manisfestations on Danio rerio embryos (Raga et al., 2014a); and exhibited analgesic property in the acetic acid writhing test and hot plate assay (Raga et al., 2014b). Another study reported that a mixture of bauerenol, $\alpha$-amyrin and $\beta$-amyrin from Carmona retusa exhibited $51 \%$ analgesic activity and showed $20 \%$ antiinflammatory activity at dosage of $100 \mathrm{mg} / \mathrm{kg}$ mouse, while of 250 $\mathrm{mg} / \mathrm{kg}$ mouse showed a $29 \%$ anti-diarrheal activity (Villasenor et al., 2004). Squalene (4) was reported to significantly suppress colonic ACF formation and crypt multiplicity**y which strengthened the hypothesis that it possesses chemopreventive activity against colon carcinogenesis (Rao et al., 1998). 
It showed cardioprotective effect which is related to inhibition of lipid accumulation by its hypolipidemic properties and/or its antioxidant properties (Farvin et al., 2006). A recent study reported that tocotrienols, carotenoids, squalene and coenzyme Q10 have anti-proliferative effects on breast cancer cells (Loganathan et al., 2013). The preventive and therapeutic potential of squalene containing compounds on tumor promotion and regression have been reported (Desai et al., 1996). A recent review on the bioactivities of squalene has been provided (Ronco and De Stéfani, 2013).

Dietary lutein (5), especially at $0.002 \%$, inhibited tumor growth by selectively modulating apoptosis, and by inhibiting angiogenesis (Chew et al., 2003). Another study reported that the chemopreventive properties of all-trans retinoic acid and lutein may be attributed to their differential effects on apoptosis pathways in normal versus transformed mammary cells (Sumantran et al., 2000). Moreover, very low amounts of dietary lutein $(0.002 \%)$ can efficiently decrease mammary tumor development and growth in mice (Park et al., 1998). Another study reported that lutein and zeaxanthine reduces the risk of age related macular degeneration (SanGiovanni et al., 2007).

$\beta$-Sitosterol (6a) was observed to have growth inhibitory effects on human breast MCF-7 and MDA-MB-231 adenocarcinoma cells (Awad et al., 2007). It was shown to be effective for the treatment of benign prostatic hyperplasia (Jayaprakasha et al., 2007). It was also reported to attenuate $\beta$ catenin and PCNA expression, as well as quench radical in-vitro, making it a potential anticancer drug for colon carcinogenesis (Baskar et al., 2010). It can inhibit the expression of NPC1L1 in the enterocytes to reduce intestinal cholesterol uptake (Jesch et al., 2009). It was reported to induce apoptosis mediated by the activation of ERK and the down regulation of Akt in MCA-102 murine fibrosarcoma cells (Moon et al., 2007).

Stigmasterol (6b) shows therapeutic efficacy against Ehrlich ascites carcinoma bearing mice while conferring protection against cancer induced altered physiological conditions (Ghosh et al., 2011). It lowers plasma cholesterol levels, inhibits intestinal cholesterol and plant sterol absorption, and suppresses hepatic cholesterol and classic bile acid synthesis in Winstar as well as WKY rats (Batta et al., 2006). Other studies reported that stigmasterol showed cytostatic activity against Hep-2 and McCoy cells (Gómez et al., 2001), markedly inhibited tumour promotion in two stage carcinogenesis experiments (Kasahara et al., 1994), exhibited antimutagenic ( $\operatorname{Lim}$ et al., 2005), topical antiinflammatory (Garcia et al., 1999), anti-osteoarthritic (Gabay et al., 2010) and antioxidant (Panda et al., 2009) activities.

\section{CONCLUSION}

Hoya multiflora is a Philippine indigenous ornamental plant with no reported chemical studies and biological activities. This study reports on the terpenoids and sterols with known diverse biological activities which were isolated from the leaves and stems of the plant. Most of these compounds (1a-1c, 3-6) were reported to exhibit cytotoxic and anticancer properties, while $\mathbf{2 a}$ 2c were reported to possess anti-inflammatory activity.

\section{ACKNOWLEGEMENT}

A research grant from the De La Salle University Science Foundation through the University Research Coordination Office is gratefully acknowledged.

\section{REFERENCES}

Anand R, Patnaik GK, Kulshreshtha DK, Dhawan N. Antiurolithiatic activity of lupeol, the active constituent of Cratevanuriala. Phytother Res 1994; 8 (7):417-421.

Aurigue FB. A Collection of Philippine Hoyas and Their Culture, Philippine Council for Agriculture, Aquaticand Natural Resources Research and Development (PCAARRD). Department of science and technology (DOST), 2013, 195 pages.

Aragão GF, Carneiro LMV, Junior APF, Bandeira PN, Lemos ILG, Viana GSdB. Evidence for excitatory and inhibitory amino acids participation in the neuropharmacological activity of alpha- and betaamyrin acetate. The Open Pharmacol J 2009; 3:9-16.

Awad AB, Chinnman M, Fink CS, Bradford PG. $\beta$-Sitosterol activates Fas signaling in human breast cancer cells. Phytomed 2007; 14:747-754.

Baas WJ, Van Berkel IEM, Versluis C, Heerma W, Kreyenbroek MN. Ring-A fissioned 3, 4-seco-3-nor-triterpene-2aldehydes and related pentacyclic triterpenoids from the leaf wax of Hoya australis. Phytochem 1992; 31 (6):2073-2076.

Baas WJ, Van Berkel IEM. 3, 4-Seco-triterpenoid acids and other constituents of the leaf wax of Hoya naumanii. Phytochem 1991; 30 (5):1625-1628.

Baas WJ. Dihydronyctanthic acid methyl ester and other 3, 4seco-pentacyclic triterpenoids from Hoya lacunosa. Phytochem, 1983; 22 (12):2809-2812.

Baskar AA, Ignacimuthu S, Paulraj G, Numair K. Chemopreventive potential of $\beta$-sitosterol in experimental colon cancer model - an in vitro and in vivo study. BMC Comp Alt Med 2010; 10:24.

Batovska DI, Todorova IT, Nedelcheva DV, Parushev SP, Atanassov AJ, Hvarleva TD, Djakova GJ, Bankova VS. Preliminary study on biomarkers for the fungal resistance in Vitis vinifera leaves, J Plant Physiol 2008; 165:791-795.

Batta AK, Xu G, Honda A, Miyazaki T, Salen G. Stigmasterol reduces plasma cholesterol levels and inhibits hepatic synthesis and intestinal absorption in the rat. Metabolism 2006; 55 (3):292-299.

Chew BP, Brown CM, Park JS, Mixter PF. Dietary lutein inhibits mouse mammary tumor growth by regulating angiogenesis and apoptosis. Anticancer Res 2003; 23 (4):3333-3339.

Desai KN, Wei H, Lamartiniere CA. The preventive and therapeutic potential of the squalene-containing compound, Roidex, on tumor promotion and regression. Cancer Lett 1996; 101:93-96.

Ebajo Jr V, Shen C-C, Ragasa CY. Triterpenes and sterol from Hoya mindorensis. Der Pharma Chemica. 2014, 6 (4):321-325.

Farvin KHS, Anandan R, Hari S, Kumar S, Shing KS, Mathew S, Sankar TV, Nair PGV. Cardioprotective effect of squalene on lipid profile in isoprenaline-induced myocardial infarction in rats. J Med Food 2006; 9 (4):531-536.

Feleke S, Brehane A. Triterpene compounds from the latex of Ficus sur I. Bull Chem Soc Ethiop 2005; 19 (2):307-310.

Gabay O, Sanchez C, Salvat C, Chevy F, Breton M, Nourissat G. Stigmasterol: a phytosterol with potential anti-osteoarthritic properties. Osteoarthritis Cartilage 2010; 18 (1):106-116.

Gallo MBC, Sarachine MJ. Biological activities of lupeol. Intl J Biomed Pharm Sci 2009; 3 (1):46-66.

García MD, Sáenz MT, Gómez MA, Fernández MA.Topical anti-inflammatory activity of phytosterols isolated from Eryngium 
foetidum on chronic and acute inflammation models. Phytother Res 1999; 13 (1):78-80.

Ghosh T, Maity TK, Singh J. Evaluation of antitumor activity of stigmasterol, a constituent isolated from Bacopa monnieri Linn aerial parts against ehrlich ascites carcinoma in mice. Orient Pharm Exp Med 2011; 11:41-49.

Gómez MA, García MD, Sáenz MT. Cytostatic activity of Achillea ageratum L. Phytother Res 2001; 15 (7):633-634.

Jabeen K, Javaid A, Ahmad E, Athar M. Antifungal compounds from Melia azederach leaves for management of Ascochyta rabiei, the cause of chickpea blight. Nat Prod Res 2011; 25 (3):264-276.

Jayaprakasha GK, Mandadi KK, Poulose SM, Jadegoud Y, Gowda GA, Patil BS. Inhibition of colon cancer growth and antioxidant activity of bioactive compounds from Poncirus trifoliate (L.) Raf. Bioorg Med Chem, 2007; 15:4923-4932.

Jesch ED, Seo JM, Carr TP, Lee JY. Sitosterol reduces messenger RNA and protein expression levels of Niemann-Pick C1-like 1in FHs 74 Int cells. Nutr Res 2009; 29 (12):859-66.

Kasahara Y, Kumaki K, Katagiri S, Yasukawa K, Yamanouchi S, Takido M. Carthami flos extract and its component, stigmasterol, inhibit tumour promotion in mouse skin two-stage carcinogenesis. Phytother Res 1994; 8 (6):327-331.

Lambertini E, Lampronti I, Penolazzi L, Khan MTH, Ather A, Giorgi G, Gambari R, Piva R. Expression of estrogen receptor gene in breast cancer cells treated with transcription factor decoy is modulated by Bangladeshi natural plant extracts. Oncology Research 2005; 14: 69-79

Lim J-C, Park JH, Budesinsky M, Kasal A, Han Y-H, Koo B-S, Lee S-I, Lee D-U. Antimutagenic constituents from the thorns of Gleditsia sinensis. Chem Pharm Bull 2005; 53 (5):561-564.

Loganathan R, Selvaduray KR, Nesaretnam K, Radhakrisnan A. Differential and antagonistic effects of palm tocotrienols and other phytonutrients (carotenoids, squalene andcoenzyme Q10) on breast cancer cells in vitro. J Oil Palm Res 2013; 25:208-215.

Lucetti DL, Lucetti ECP, Bandeira MAM, Veras HNH, Silva AH, Leal LKAM, Lopes AA, Alves VCC, Silva GS, Brito GA, Viana OB. Anti-inflammatory effects and possible mechanism of action of lupeol acetate isolated from Himatanthus drasticus (Mart.) Plumel. J Inflam 2010; 7:60.

Madeiros R, Otuki MF, Avellar MC, Calixto JB. Mechanisms underlying the inhibitory actions of the pentacyclic triterpene-amyrin in the mouse skin inflammation induced by phorbol ester 12-Otetradecanoylphorbol-13-acetate. Eur J Pharmacol 2007;55 (9):227-235.

Manzano PI, Miranda M, Abreu-Payrol J, Silva M, Sterner O, Peralta EL. Pentacyclic triterpenoids with antimicrobial activity from the leaves of Vernonanthura patens (Asteraceae). Emir J Food Agric 2013; 25 (7):539-543

Moon DO, Kyeong Jun L, Yung HC, Gi-Young K. Moon DO, Kyeong Jun L, Yung HC, Gi-Young K. Int Immunopharmacol 2007; 7:1044-1053.

Okoye NN, Ajaghaku DL, Okeke HN, Ilodigwe EE, Nworu CS, Okoye FBC. beta-Amyrin and alpha-amyrin acetate isolated from the stem bark of Alstonia boonei display profound anti-inflammatory activity. Pharm Biol 2014; 52 (11):1478-1486.

Otuki C, Ferreira J, Lima F, Meyre-Silva C, Malheiros A, Muller L, Cani G, Santos A, Yunes R, Calixto J. Antinociceptive properties of a mixture of $\alpha$-amyrin and $\beta$-amyrin triterpenes: evidence for participation of protein kinase $\mathrm{C}$ and protein kinase A pathways. J Pharmacol Exp Therapeutics 2005; 31 (1):310-318.

Panda S, Jafri M, Kar A, Meheta BK. Thyroid inhibitory, antiperoxidative and hypoglycemic effects of stigmasterol, isolated from Butea monosperma. Fitoter 2009; 80 (2):123-126.

Pandey SC, Singh SS, Ghosh AC, Deepak D, Khare AJ. Med Arom Plant Sci 2004; 26 (4):775-783.

Park JS, Chew BP, Wong TS. Dietary lutein from marigold extract inhibits mammary tumor development in BALB/c mice. $J$ Nutr1998; 128 (10):1650-1656.

Raga DD, Herrera AA, Ragasa CY. Angio-suppressive triterpenoids from Ardisia cf. elliptica (subgenus Tinus) on duck (Anas platyrynchos L.) chorioallantoic membrane. Chin J Nat Med 2013a; 11 (2):128-138.

Raga DD, Herrera A, Shen C-C, Ragasa CY. Triterpenes from Ardisia cf. elliptica (subgenus Tinus) limit vascular density and promote von Willebrand factor expression on duck chorioallantoic membrane. Pharm Chem J 2013b; 47 (1):44-53.

Raga DD, Herrera AA, Dinah Espineli, Shen C-C, Ragasa CY. Triterpenes from Ardisia squamulosa C. Presl (Myrsinaceae) limit angiogenesis and the expression of Von Willebrand factor in duck chorioallantoic membrane. J Chem Pharm Res, 2013c; 5 (10):230-239.

Raga DD, Herrera AA, Alimboyoguen AB, Shen C-C, Ragasa CY. Effects of triterpenes from Ardisia cf. elliptica (subgenus Tinus) and sterols from Ardisia pyramidalis Cav Pers on Artemia salina and Danio rerio toxicity and caudal fin regeneration. J Chem Pharm Res 2014a; 6 (3):1014-1022.

Raga DD, Herrera AA, Shen C-C, Ragasa CY. Analgesic triterpenes from Ardisia cf. elliptica (subgenus Tinus) (Myrsinaceae). Der Pharma Chemica 2014b; 6 (4):153-161.

Ragasa CY, Caro JL, Shen C-C. Triterpenes and sterol from Artocarpus ovatus. J Appl Pharm Sci aawaaw2014a; 4 (10):7-11.

Ragasa CY, Ng VAS, De Los Reyes MM, Mandia EH, Shen CC. Triterpenes and a coumarin derivative from Kibatalia gitingensis (Elm.) Woodson. Der Pharma Chemica 2014b; 6 (5):360-364.

Ragasa CY, Ng VAS, Ebajo Jr V, De Los Reyes MM, Mandia EH, Shen C-C. Chemical constituents of Wrightia pubescens (R.Br.). Der Pharmacia Lettre 2014c; 6 (6):14-19.

Ragasa CY, Torres OB, Mandia EH, Shen C-C. Chemical constituents of Terminalia microcarpa. Der Pharmacia Lettre 2014d, 6 (6):439-442.

Ragasa CY, Caro JL, Lirio LG, Shen CC. Chemical constituents of Coix lacryma-jobi. Res J Pharm Biol Chem Sci 2014e, 5 (6):344-348.

Rao CV, Mark HLN, Reddy RS. Chemopreventive effect of squalene on colon cancer. Carcinogenesis 1998; 19:287-290.

Recio MC, Giner RM, Manez S, Rios JL. Structural requirements for the anti-inflammatory activity of natural triterpenoids. Planta Med 1995; 61 (2):181-185.

Reddy KP, Singh AB, Puri A, Srivastava AK, Narender T. Synthesis of novel triterpenoid (lupeol) derivatives and their in vivo antihyperglycemic and antidyslipidemic activity. Bioorg Med Chem Lett 2009; 19:4463-4466.

Ronco AL, De Stéfani E. Squalene: a multi-task link in the crossroads of cancer and aging. Functional Foods in Health and Disease 2013; 3:462-476.

Saleem M, Maddodi N, Zaid MA, Khan N, Hafeez B, Asim M, Suh Y, Yun J, Setaluri V, Mukhtar H. Lupeol inhibits growth of highly aggressive human metastatic melanoma cells in vitro and in vivo by inducing apoptosis. Cancer Therapy: Preclinical 2008; 14:2119-2127.

Saleem R, Ahmad SI, Ahmed M, Faizi Z, Zikr-ur-Rehman S, Ali M, Faizi S. Hypotensive activity and toxicology of constituents from Bombax ceiba stem bark. Biol Pharm Bull 2003; 26: 41-46.

SanGiovanni JP, Chew EY, Clemons TE, The relationship of dietary carotenoid and vitamin $\mathrm{A}, \mathrm{E}$, and $\mathrm{C}$ intake with age-related macular degeneration in a case-control study: AREDS Report No. 22. Arch Ophthalmol 2007; 125 (9):1225-1232.

Santos FA, Frota JT, Arruda BR, de Melo TS, de Carvalho AA, da Silva A, Brito GAdC, Chaves MH, Rao VS. Antihyperglycemic and hypolipidemic effects of $\alpha, \beta$-amyrin, a triterpenoid mixture, from Protium heptaphyllum in mice. Lipids in Health and Disease 2012; 11:98.

Soldi C, Pizzolatti G, Luiz A, Marcon R, Meotti F, Miotob L, Santos A. Synthetic derivatives of the $\alpha$ - and $\beta$-amyrin triterpenes and their antinociceptive properties. Bioorg Med Chem 2008; 16 (6):33773386.

Sumantran VN, Zhang R, Lee DS, Wicha MS. Differential regulation of apoptosis in normal versus transformed mammary epithelium by lutein and retinoic acid. Cancer Epidemiol Biomarkers Prev 2000; 9:257-263.

Tsai P-W, de Castro-Cruz K, Shen C-C, Ragasa CY. Chemical constituents of Ficus odorata. Pharm Chem J 2012b; 46 (4):225-227. 
Vasconcelos JF, Teixeira MM, Barbosa-Filho JM, Lúcio ASSC, Almeida JRGS, Queiroz LP, Ribeiro-dos-Santos R, Soares MBP. The triterpenoid lupeol attenuates allergic airway inflammation in a murine model. Intl Immunopharmacol 2008; 8:1216-1221.

Vázquez LH, Palazon J, Navarro-Ocaña A. (2012). The pentacyclic triterpenes, $\alpha, \beta$-amyrins: A review of sources and biological activities, Phytochemicals - A Global Perspective of Their Role in Nutrition and Health, Rao V (Ed.), ISBN: 978-953-51-0296-0, InTech, Available from: http://www.intechopen.com/books/phytochemicals-aglobal-perspective-of-their-role-in-nutrition-and-health/the-pentacyclictriterpenes-amyrins-a-review-of-sources-and-biological-activities.

Vidya L, Leni M, Varalakshmi P. Evaluation of the effect of triterpenes on urinary risk factors of stone formation in pyridoxine hyperoxaluric rats. Phytother Res 2002; 16 (6):514-518.

Villasenor IM, Canlas AP, Faustino KM, Plana KG. Evaluation of the bioactivity of triterpene mixture isolated from Carmona retusa (Vahl.) Masam leaves. J Ethnopharmacol 2004; 92 (1):53-56.
Yoshikawa K, Nishino H, Arihara S, Chang HC, Wang JD, Oligosaccharides from Hoya carnosa. J Nat Prod 2000; 63 (1):146-148.

Zhang L, Zhang Y, Zhang L, Yang X, Lv Z. Lupeol, a dietary triterpene, inhibited growth, and induced apoptosis through downregulation of DR3 in SMMC7721 cells. Cancer Investigation 2009; $27: 163-170$

\section{How to cite this article:}

Ebajo Jr. V., Shen C-C., Ragasa C.Y. Terpenoids and Sterols from Hoya multiflora Blume. J App Pharm Sci, 2015; 5 (04): 033-039 